\title{
Clearing of researcher in "Baltimore affair' boosts demand for reforms
}

Washington. Ten years after charges of scientific misconduct were first levelled against her, Thereza Imanishi-Kari, an immunologist at Tufts University Medical School in Boston, has been cleared of wrongdoing by the appeals board of the US Department of Health and Human Services (DHHS).

The board's decision, released in Washington last Friday, overturns a highly publicized ruling in 1994 by the Office of Research Integrity (ORI) of the National Institutes of Health (NIH), which found Imanishi-Kari guilty of scientific misconduct and fraud (see Nature 372, 391; 1994).

This followed allegations that data in a laboratory notebook concerning experiments on gene expression in transgenic mice, carried out between 1984 and 1986 at the Massachusetts Institute of Technology (MIT) in collaboration with David Baltimore, then head of the MIT's Whitehead Institute, appeared to contradict data published in a paper in the journal Cell at the end of this period.

The Imanishi-Kari affair has become more than a solitary case of alleged scientific

misbehaviour; for many, it now represents the worst aspects of government handling of scientific misconduct allegations. By overruling the ORI verdict, the appeals board has opened the door to calls for reform of the current system for dealing with allegations of scientific misconduct.

But the most immediate impact of the appeals board ruling is to

\section{IMAGE UNAVAILABLE} FOR COPYRIGHT REASONS clear Imanishi-Kari herself. "This is Imanishi-Kari: likely to absolutely fantas- seek reinstatement. tic, but I haven't

had time to enjoy it," she said the day after the verdict. "I am so pleased that there are some honest people who can make a fair judgement."

Imanishi-Kari currently works as a research associate in the department of pathology at Tufts. She held a faculty appointment at the university until the ORI verdict forced the university to strip it from

\section{Problems of integrity are 'pervasive'}

Washington. The chairman of a congressionally-mandated commission on misconduct in research has hit back at critics who claim that the recommendations of a recent report by the panel are too draconian, and has warned that problems of integrity are now "pervasive" in US science.

Kenneth Ryan, professor emeritus at Harvard Medical School and chairman of the Commission of Research Integrity (CRI), says that its proposals must be acted on because the scientific community has ignored a report published in 1992 by the National Academy of Sciences, which recommended extensive self-regulation of scientific conduct.

He also predicted that Donna Shalala, the health secretary, will implement most of the CRI's recommendations, despite the protests of scientists and groups such as the Federation of American Societies for Experimental Biology (see Nature 381, 639; 1996).

"It isn't the commission that is on trial here - it is the scientific community," he told a seminar in Washington last week organized by George Washing- ton University and the American Association for the Advancement of Science.

Ryan hit out at scientists who have attacked the 12-man panel for its failure to include "distinguished" scientists. "That's such an easy thing for scientists to say," said Ryan. "The twelve were chosen to represent the public interest, not scientists' interests."

Congress set up the panel in 1993, and Shalala is now considering its recommendations. "I'm very, very cynical about the scientists who are protesting so much" about the CRI findings, Ryan said. "I'd like to see them stand up for what was in the National Academy of Sciences report."

Speaking before the final verdict, delivered four days later, in the long-running case involving David Baltimore, the Nobel prizewinner, and Thereza ImanishiKari (see above), he also warned scientists not to draw comfort from the result. "If Imanishi-Kari is exonerated, I can see a lot of people saying that there is 'no problem'. But there is more to [scientific integrity] than these high-profile cases."

Colin Macilwain her, although university officials have allowed her to continue her laboratory research pending the result of the appeal.

The case began in 1986, when the allegations against her were made by Margot O'Toole, a postdoctoral research fellow in Imanishi-Kari's laboratory. O'Toole took her concerns to both MIT and Tufts University, which was considering Imanishi-Kari for a position at the time. Officials at both institutions decided that the dispute was of a kind "not uncommon in science".

O'Toole's persistence in questioning the Cell paper led the NIH to set up a panel of inquiry. This found errors in the paper requiring correction, but no evidence of "fraud, misconduct, manipulation of data, or serious conceptual error". But by then the House of Representatives, through John Dingell (Democrat, Michigan), chairman of the oversight and investigations subcommittee of the Committee on Energy and Commerce, had opened hearings into the matter.

Baltimore's spirited public defence of Imanishi-Kari at the hearings led to the case becoming informally known as "the Baltimore affair", even though Baltimore himself was never accused of misconduct. (His intervention also cost Baltimore the presidency of Rockefeller University.)

Dingell, a tireless critic of the 'self-policing' policy of the US scientific community, enlisted the US Secret Service to conduct forensic studies of some of Imanishi-Kari's laboratory notebooks, including analysis of their paper and ink, as well as the radiation counter tapes they contained, to establish the dating of relevant experiments.

According to the Secret Service forensic experts testifying before the appeals board, there were some inconsistencies that could be construed as fabrication of data. But they were quick to add under questioning that they had no previous experience in analysing laboratory notebooks.

Nevertheless, ORI eventually found Imanishi-Kari guilty on 19 counts of scientific misconduct and banned her from receiving federal research grant money for ten years. Imanishi-Kari appealed against the verdict to the DHHS departmental appeals board in November 1994, and the verdict was finally delivered last week.

The panel appointed to hear the appeal has now ruled that "no debarment be imposed" and that "no other administrative actions should be taken", effectively closing the case for good.

But the publicity that has surrounded the case means that its fallout is likely to be 
- felt for some time. Joseph Onek, for example, the lawyer for both Imanishi-Kari and Baltimore, says that the appeals board's ruling is a "great thing for Dr Imanishi-Kari, but $I$ also think it is a great thing for science". He adds: "I hope that this case will now lead the government and scientific community to reassess how these scientific misconduct disputes are handled, and try to figure out ways to resolve them more promptly and fairly."

ORI, never popular among scientists, is now likely to lose even more support. Indeed, the heaviest criticism in the appeals board's ruling was levelled at the integrity office, saying that much of the evidence it presented was "irrelevant, had limited probative value, was internally inconsistent, lacked reliability or foundation, was not credible or not corroborated, or was based on unwarranted assumptions".

The appeals board ruling comes at a time when proposed new scientific misconduct regulations are being hotly debated both within DHHS and in the scientific community at large. How the department should respond to a congressionally mandated report on scientific misconduct is being considered by Shalala and her staff (see Nature 639, 381; 1996 and previous page).

In addition to ORI, another likely casualty of the appeals board ruling is O'Toole, now a researcher at the Genetics Institute, a private biotechnology company in Cambridge, Massachusetts. "The [board] has had the same initial reaction everybody has had: they can't believe that what I said happened, did in fact happen," says O'Toole. "But since they have tossed out the evidence, their conclusions are not surprising."

The appeals board called O'Toole's interpretations of some events "improbable and unwarranted", and parts of her testimony "not credible". But O'Toole takes issue with such statements. "From the beginning, I have always told the truth, with the full expectation I would be branded a liar for doing so," she says. "The miracle was that, without exception, every scientist who examined the evidence, eventually - and reluctantly - came to the conclusion I was telling the truth."

The panel said it was important that for 'whistleblowers' to be protected from adverse consequences. But it also warned that they should not get too heavily involved in a subsequent investigation. "Such involvement can compromise both the ability of the investigators to maintain objectivity, and the ability of the whistleblower to avoid becoming too vested in the outcome," it says. "We think that happened here."

Imanishi-Kari says that her first priority now is to seek reinstatement of her faculty position at Tufts University, a request which is likely to be granted by the university, which has been "very supportive" through the whole affair. "Then I will be back to the usual," she says. "Trying to get funding for my research."

Fintan Steele

\section{Italian minister promises to cut research bureaucracy}

Rome. Luigi Berlinguer, Italy's new research and education minister, promised last week that research will be one of the new government's highest priorities - even though pre-election pledges of increased funding may have to wait for improvements in the economy.

After one month in office, Berlinguer says he is keen to increase the cost-effectiveness with which Italy spends its research budget, in particular by requiring its notoriously bureaucratic research and university systems to increase their efficiency.

But he wants to do this as far as possible without introducing new laws into

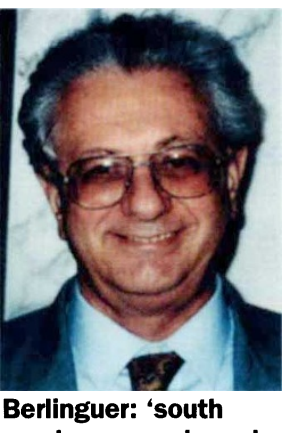

needs more science' areas which, he says,

already suffer from excessive legislation. At the same time, Berlinguer plans to introduce radical changes to the recruitment of university faculty members, raise support for scientists in the relatively impoverished south of Italy, and push for increased joint research funding by the European Union (EU).

Berlinguer is a member of the Democrat Party of the Left (PDS) - the successor to the former communist party - with long parliamentary experience. He was even made research minister in Carlo Ciampi's interim government in 1993, but his appointment lasted only a few hours before the PDS pulled out of the government.

One of his major targets, he says, is Italy's National Research Council (CNR), which funds around 350 research institutes and university centres. Scientists have long been frustrated by extensive delays in allocating CNR funds, and what they claim to be a general mismanagement of resources.

Many argue that the roots of such problems lie in the highly centralized organization that has existed since the research body was first established by Benito Mussolini in the early 1920s. Berlinguer says that he plans to push for the full implementation of a law drawn up at the end of the 1980 s by Antonio Ruberti, the former research minister, giving institutes sufficient autonomy to make their own internal regulations and control their own budgets.

At the same time, he plans to speed up grant review processes and simplify administrative procedures carried out through CNR's central headquarters, where staff numbers will be cut by relocating administrative positions to individual institutes.

A similar approach will be taken to the
CNR's 15 scientific advisory committees, which Berlinguer says are both too numerous and too large. Broader reform of the committee system, which would require an act of parliament, may follow later.

One area where he is already planning legislative action is reform of the controversial system of appointing university staff through national competitions - or concorsi - widely criticized for giving considerable weight to the personal connections of candidates (see Nature 378, 228; 1995).

Attempts by previous ministers to change the system have been unsuccessful, largely because of resistance from parliamentary professors who have themselves benefited from it. Although the parliament is still dominated by university professors, Berlinguer - who is himself professor of law at the University of Siena - hopes that fresh blood will judge more favourably his own radical reform proposals, the details of which will be announced shortly.

Another of Berlinguer's priorities is to find ways of recruiting more young scientists in southern Italy, where the proportion of researchers in the population is six times lower than in the industrialized north.

Various programmes to improve the science base of the south have been introduced by previous governments over the past few years, but he says that there is little to show for the IL1,000 billion (US\$640 million) invested so far. "The idea that money could be rained down on the south and that would be enough to make things work was ill-conceived. In future, it must be clear that the infrastructure is there to support research programmes."

The programmes will be relaunched, but with more checks and controls to ensure that investments are better protected. In addition, says Berlinguer, a recruitment drive will be introduced for young scientists, offering a large number of scholarships and temporary research contracts.

Even though Italy cannot afford to raise its relatively low level of investment in research - despite being the fourth largest economy in Europe, it spends only 1.3 per cent of its gross national product on research and development, barely half that of many other European countries - it will still propose an increase in the EU's fifth Framework programme of research, which will run from 1998 to 2002 .

Berlinguer justifies this on the grounds that Europe can only compete effectively with Japan and the United States if member states join forces as extensively as they can, although others point out that Italy would hope to be a net beneficiary of any increased spending on Framework.

Alison Abbott 